\title{
An Empirical Study for the Correlation Between Disclosed Related Party Transactions and the Market Value of Companies Listed on the Amman Stock
} Exchange

\author{
Hisham Mohammed Ahmed Al-Shayeb ${ }^{1, *} \&$ Tawfiq H. Abdel-Jalil ${ }^{2}$ \\ ${ }^{1}$ The World Islamic Sciences \& Education University, W.I.S.E, Jordan \\ ${ }^{2}$ Accounting Department, University of Jordan, Jordan \\ *Corresponding author: Phd Candidate - The World Islamic Sciences \& Education University \\ W.I.S.E, Jordan. E-mail: alshayeb82@yahoo.com
}

Received: June 3, 2021 Accepted: September 29, 2021 Published: November 9, 2021

doi: 10.5296/jegr.v5i1.19169 URL: https://doi.org/10.5296/jcgr.v5i1.19169

\begin{abstract}
This study examines the correlation between related parties' transactions (RPT) and company's market value in Jordan. In this study the related party transactions were covered through operationalized into three forms that are: Transactions with parent company, subsidiaries and affiliated companies (TPSAC), Transactions with associated companies (TAC) and Transactions with main shareholders, directors and/or managers (TMSDM), in order to see the impact on company's value.

This study considered all the companies listed in Amman Stock Exchange (ASE) at the end of year 2018 with total number of 226 companies for all sectors. After excluding companies with missing data, the final sample size was 218 companies; covering almost $96 \%$ of population. Multiple regression test was used to examine the study's hypotheses. The result of the study indicates that the related party transactions (RPT) Shown a positive effect on (TQ) which represents the company's value with presence of the control variables (audited by one of the big four audit firms (BIG), size of the company (SIZE), return on assets (ROA), and dividend yield (DIV). The results also show the increasing influence of the independent variable on the dependent variable with presence of the control variables.
\end{abstract}

Keywords: related party transactions, audit firms, company's value, agency conflict, ownership structure 


\section{Introduction}

Recently, the related party transactions are widely observed in the business activities, as the companies enter into various transactions which may violate the arm's-length assumption of regular transactions with their related parties (i.e. shareholders, directors / key managers, parent company, subsidiaries, affiliated or associated companies) in the normal course of business concerning financing and other services where the prices, costs and terms of payments are approved by the company's management. Therefore significant related party transactions which disclosed in the financial statements may have a direct positive / negative impact on the company's value. And in certain studies, the authors concluded that there is no significant relationship between RPTs and company value (Diab, et al, 2019).

In this manuscript, we find that it is necessary to draw attention for the for the RPTs disclosure and to enhance the standards of financial statements risk of non-disclosing the balances or transactions with related parties which should be mitigated by linking with the company's profitability.

In MENA region it was widely noticed that most of the directors, key managements personnel and the principals managing the companies are either themselves, their families or relatives, and the conclusions in certain papers finds that it remains premature to say that a unique MENA model of corporate governance currently exists (Piesse, et al., 2012). A study of Jordanian researchers examine the impact of ownership structures and the level of accounting conservatism which finds an inverse effect of governmental ownership on accounting conservatism, but the concentration of ownership doesn't affect conservatism (A1 Kurdi et al. 2017). This phenomenon is shedding the light on the agency conflict concept; which is the conflict of interest that can arise between shareholders (principals) and managers controlled or could be eliminated. This view will affect the potential costs and benefits of the transaction between shareholders (principals) and related parties with subsequent results that could fulfill economic gain or harm of the company, also, some papers support findings of previous researches which finds that good corporate governance, leads to better access to capital at lower cost ( Ramachandran, et al. , 2020).

Through related party transactions, the opportunistic management can increase its wealth at the loss of the shareholders or on the other hand the major shareholders can dispossess the wealth of the non-controlling interest through manipulation of related party transactions (Peirsona et al. ,2015) and (Fanania and Alya Firdausib ,2020).

Another view; most of the non-controlling or minority shareholders who have a limited voting right in the board meetings are dealing with shares in the financial market by disposing or not buying the company's shares of companies that have transactions with related parties, thus decreasing the demand on the shares which could decrease the share price and affects the company's value negatively (Kohlbeck and Mayhew, 2010), (Weiju. and Cherif, 2011) and (Yeh, et al., 2012).

On November 2009, one of the Big Four accounting firms which plays a crucial role in the social construction of professional identity is KPMG issued a publication called "First 
Impression of amendments to IAS24 - related party disclosure mentioning that when an associated companies of an investor prepares its separate financial statements it treats that investor in its financial statements as a related party. If the investor has affiliates, then these affiliates also are treated as related to the associated companies, because they form part of the group, which has significant influence over that associate. Conversely, if a subsidiary of the investor prepares its separate financial statements, then the above mentioned associated company does not meet the definition of a related party under IAS24. They have noted however, that in their view under IAS24 it is preferable to treat affiliated and associated companies of the parent of ultimate parent as related parties to a subsidiary, unless it is clear that the relationship has no current or potential impact on the company's market value, operations or results.

\subsection{Research Objective}

Recently, in Jordan the related party transactions (i.e. related sales, lending, guarantee and related borrowings) are widely observed in the business activities, as the entities enter into various transactions which may violate the arm's-length assumption of regular transactions with their related parties (i.e. shareholders, key management personnel, associates, subsidiaries and other related parties) in the normal course of business concerning financing and other related services where the prices and terms of payments are approved by the entities management.

Therefore significant related party transactions and balances should be fairly disclosed in the financial statements which may have a direct impact on the company's market value.

This study is designed to test the association between related party transactions disclosed (Independent Variable) and the company's market value (Dependent Variable) as the researcher expects that this study results will give justifications of associations between study variables and expects that RPTs effect on firm market value the most interest of all shareholders in the companies listed in stock exchange who are expecting that the regulations issued by stock exchange commission protects their rights and investments.

\subsection{Research Importance}

After the bankruptcy issue (i.e.: Enron), expropriation through related party transactions has drawn the attention of regulators and researchers in recent years (Y.Zhu and X.Zhu, 2012). This study will highlight certain implications of empirical findings for company's management, regulatory agencies and the major and minority shareholders. In this regard, related party transactions can be used for positive purposes, such as:

Internalization of market transactions to achieve economies of scale, to optimize the allocation of internal resources and to enhance overall enterprise competitiveness; to reduce the risk associated with external market transactions; and subsequently reducing transaction time and transaction costs.

Therefore, related party transactions can help a company to create value, rather than merely boosting the companies reported earnings through earnings management. 
This study can be considered as complement for previous studies related party transactions by showing that the related party transactions can be either damaging the company's market value or helping a company to create market value.

To our knowledge, in year 2015 this was the first study in Jordan that analyzes and discusses the correlation between related party transactions disclosure and the company's market value at the time most of the business in Jordan considered as family business where we can find that the related party transaction incurred frequently.

Section two includes review of previous studies (literature review) and the theoretical framework of the relationship between the variables to be tested. Section three explains the research methodology; variables and operational definition, Conceptual Model, hypotheses, research population, sample Selection and data collection method, model, measurement of variables and statistics. Section four presents the data analysis results which includes; descriptive analysis, variance inflation factor (VIF), matrix of correlation coefficients between study variables and hypotheses testing. Conclusions and recommendations are presented in Section five.

\section{Literature Review}

In this section, there are two hypotheses generated through the thorough review of previously published literature; the first one is the conflict of interests; opportunistic management that harms the company's value and considers only the interest of directors. And the second is the fair efficient RPTs hypothesis considering them as economic exchanges may have a positively impact on the company's value (Pizzo, 2013) and (Rayngaert and Thomas, 2012). Most researchers have defined the first hypothesis that the related party transactions have a potentially negative effect on company's value (Kohlbeck and Mayhew, 2010), (Nekhili and Cherif, 2011) and (Yeh, et al., 2012).

Cheung et al.(2011), analyzed related party transactions between Chinese publicly listed firms and their state-owned shareholders to examine whether companies benefit or lose from the presence of government shareholders and politically connected directors, they concluded that the minority shareholders seem to be expropriated in firms controlled by local governments, firms with a large proportion of local government directors on their board, firms without central government directors, and firms in provinces where local government bureaucrats were less likely to be prosecuted for corruption. In contrast, firms controlled by the central government, benefit in related party transactions with their government parents.

Kohlbeck and Mayhew (2010) examined the stock market's valuation of companies' that disclose related party transactions compared to those that do not. They examined market values just prior to the Sarbanes-Oxley Act (SOX) ban on related party loans to evaluate the market's perception of firms with related party transactions prior to regulatory intervention. They also evaluated subsequent outcomes to assess the related party companies' overall risk return profile. Their market analysis suggests that related party companies' have significantly lower valuations and marginally lower subsequent returns than non- related party firms. 
Market perceptions differ based on partitioning firms by related party transactions type and parties. The results are consistent with the market discounting companies that involve in simple related party transactions. Overall, (Kohlbeck and Mayhew, 2010) research results suggested that the market assigned lower market values to companies that engage in specific types of related party transactions. They document both lower valuations and subsequent returns for related party firms. Further analyses exploring differences in transaction types suggest companies with simple transactions with DOS drive the negative valuation and returns findings. The related party loans banned by SOX appear to have particularly strong negative valuation implications, and marginal negative returns.

Nekhili and Cherif (2011), in their research were trying to identify the ownership structure and governance characteristics of companies that engage in related party transactions, the study has shown that a large number of managers, directors and main shareholders have been accused of having significant role in the various positions that led to the collapse of relatively large companies or groups of companies. Also, based on the selected companies sample listed on the Paris Stock Exchange during the period 2002-2005, which concludes that transactions directly with the major shareholders, and made indirectly via subsidiaries or affiliates, has depreciated the value of the entity. These transactions are the most damaging to small shareholders, and they are determined mainly by the voting rights held by the main shareholders. The size of the board of directors increases the frequency of related party transactions. As well, the presence on the board of independent directors and an audit committee calls out for review.

Although they make a marked contribution to reduce transactions with subsidiaries and affiliated companies, independent directors, paradoxically this seems to foster transactions made with the main shareholders, directors and/or managers. Furthermore, the presence of an audit committee seems to be effective only in reducing transactions made with subsidiaries and affiliated companies. Its degree of independence serves only to strengthen its impact on this category of transaction, but has no effect at all on transactions potentially entailing expropriation.

The result of Chen, et al. (2011) study "Related party transactions as a source of earnings management" are consistent with the extant literature of earnings management through subsidiaries transactions in Japan (Thomas, et al., 2004), that suggests Japanese parent companies use related party transactions with their subsidiaries companies to maximize their earnings. In addition, they mentioned that their findings can be generalized to other institutional regimes in Asia, where public companies usually have a pyramidal ownership structure. As (Friedman, et al. 2003) pointed out, in countries with weak legal systems, controlling entrepreneurs conduct transactions to tunnel economic resources out of listed firms and expropriate the interests of minority investors.

Under high uncertainty, such as a financial crisis, controlling shareholders prop up their companies and use their private resources to benefit minority shareholders, and this was the case in South Korea (Friedman, et al., 2003), Hong Kong (Cheung, et al., 2006) and Singapore (Riyantoa and Toolsema, 2008). In this area, in a regime with weak legal systems 
and concentrated ownership structure (Johnson and Shleifer, 2004), related party transactions between controlling shareholders and listed firms can be used for opportunistic goals. Therefore, they could reasonably expect that related party transactions between controlling shareholders and listed firms in a regime with weak legal system and concentrated ownership structure may be used in a way to artificially enhance operating performance of listed firms under certain circumstances.

Yeh, et al. (2012), explored how corporate governance affects the level of related-party transactions (RPTs) and how it moderates the motives of using RPTs in Taiwan, an ownership-concentrated economy. The empirical results showed that good corporate governance was effective in constraining RPTs with the negative relation being sustainable across different measures of RPTs (raw, residual and industry-adjusted RPTs) and across different types of RPTs (related sales, lending and guarantee, and related borrowings). The propping-up hypothesis indicates that the level of related sales is positively correlated with the condition that firms plan to issue seasoned equity next period and the condition of a decrease in the reported earnings. The internal capital market hypothesis indicates that the level of related lending and guarantee (related borrowing) is positively/ negatively correlated with the condition of an increase in capital expenditure and an increase in net working capital. The empirical results lend partial support to the two hypotheses. More importantly, they found that corporate governance moderates the relation between the motives and the level of RPTs. The findings of this study enhance their understanding of how firms are motivated and how governance quality affects the use of RTPs. Even though RPT by definition might not be equivalent to wealth exploitation, its excessive use is problematic. This study contributed to the existing literature by breaking down RPTs into subcategories and gauging level of use with different models. The results portray the importance of corporate governance in reducing the level of RPTs. Some issues could be further explored in the future studies.

Wang and Yuan (2012) showed in their research "The Impact of Related Party Sales by Listed Chinese Firms on Earnings Informativeness and Earnings Forecasts" an adverse impact of related party sales of goods and services on the usefulness of accounting earnings to investors and on the quality of earnings forecasts by financial analysts. They suggested that related party transactions impair the representational faithfulness and verifiability of accounting data. They focused on related party sales of goods and services because they affect accounting earnings more directly than other types of related party transactions such as directors' loans.

Their paper results also suggest that financial analysts should not be unduly willing to trust earnings numbers that are contaminated by unreliable related party sales. However, the limitation is that financial analysts cannot observe the quality of related party sales directly from companies' financial disclosures. Thus they should acquire more private information about related party sales.

Maggie et el., (2013) investigated the phenomenon in China of listed companies the Corporate propping through related-party transactions, their study has addressed a gap in the literature on providing up-to-date evidence of extent to which government regulatory factors 
in China concerning the maintenance of threshold return on equity (ROE) levels and the releasing of non-tradable shares to the market, created or limited the potential for emergence of a market for ownership control, and consequently that has affected the extent of propping as reflected in abnormal sales to related parties. The primary result of this research was that the company's risk of being classified as a special treatment firm by regulatory authorities when its ROE gets close to a regulatory threshold is significantly associated with greater propping. The second important conclusion was that the proportion of non-tradable shares retained by a state-based controlling shareholder from a government allocation is significantly associated with lower propping. The inference is non-tradable shares are seen to provide a barrier to competition for control of the listed company rather than an opportunity to raise greater equity capital for growth.

Pizzo (2013), examined in his paper both theories; (a) conflict of interests, considering these dealings as potentially harmful and carried out in the interest of directors; (b) efficient transaction hypothesis, describing them as sound economic exchanges critically through a deductive approach, and also on the basis of their economic rationale. Then, a contingency perspective he suggested, underling how the effectiveness and the efficiency of the proposed solutions are strictly correlated to organizational contexts, institutional environments and governance practices. His paper results so far highlighted the existence of inconsistencies in both the above mentioned theories.

Bona-Sanchez, et al. (2017), study's major concern of corporate governance was the potential expropriation of non-controlling interests by controlling owners, related party transactions need special regulations and regulators attention in order to improve investor protection and market confidence to promote more efficient allocation of entity's resources.

Pratama (2018), study results conclusion was to increase efficiency of operations, companies have to engage in several activities such as related party transactions and tax avoidance (TA). And mentioned that in the previous studies shows inconsistencies as to whether these actions influence company's value positively or negatively.

\subsection{Theoretical Framework}

After deep review of published studies in the literature, summarizing their conclusions and recommendations, and to resolve the research problem; the conceptual model of this study has been constructed (Figure 1 - page 23). RPTs activities are very important to outside shareholders and other related parties than those who are acting as directors or managers running the business in the company to maximize their wealth. To protect the rights of the outside shareholders Amman stock exchange commision (ASEC) is asking all listed companies to disclose detailed information regarding RPTs. In the collapse of Enron, most shareholders and other related parties losses were directly resulted of RPTs. The documentation of RPTs for outside shareholders and other related parties differs according to the historical origins of the transactions (Rayngaert and Thomas, 2012).

In normal course of business, most of RPTs are executed between:

1- Shareholders: are individuals or company who have shares in the reporting company. 
2- Parent company: which have control over the company (in common owns more than $51 \%$ of the company's share).

3- Sister or affiliated companies: which controlled by the same parent company.

4- Subsidiaries: which are those enterprises controlled by the company. Control exists when the parent company has the power, directly or indirectly, to govern the financial and operating policies of an enterprise so as to obtain benefits from its activities. Inter-company balances and transactions, including inter-company profits and unrealized profits and losses are eliminated on consolidation based on that our study focus on the transactions disclosed in the nonconsolidated financial statements of the subsidiaries as its only eliminated in the parent company's financial statements.

5- Associated companies: which are those enterprises in which the company has significant influence, but not control, over the financial and operating policy decisions.

6- Key management personnel: which includes their benefits and compensations.

The following factor areas have often been considered as critical factors that affect the company's value. The following section briefly explains those factors:

\subsection{Related Party Transactions (RPTs) And Company's Value}

A related party is a person or company that is related to the reporting company.

- (a) A person or a close member of that person's family is related to a reporting company if that person:

(i) has a control or joint control over the reporting company; is called parent company,

(ii) has significant influence over the reporting company; is called associated company or,

(iii) is a member of the key management personnel of the reporting company or of a parent of the reporting company.

- (b) A company is related to a reporting company if any of the following conditions applies:

(i) The company and the reporting company are members of the same group (which means that each parent, subsidiary and affiliate is related to the others).

(ii) One company is an associate or joint venture of the other company (or an associate or joint venture of a member of a group of which the other company is a member).

(iii) Both companies are joint ventures of the same third party.

(iv) A company is a joint venture of a third company and the other company is an 
associate of the third entity.

(v) The company is a post-employment defined benefit plan for the benefit of employees of either the reporting company or a company related to the reporting company. If the reporting company is itself adopting such a plan, the sponsoring employers are also related to the reporting company.

(vi) The company is controlled or jointly controlled by a person identified in (a).

(vii) A person identified in (a) (i) has significant influence over the company or is a member of the key management personnel of the company (or of a parent of the company).

A related party transaction (RPT) is a transfer of resources, services, or obligations between related parties, regardless of whether a price is charged (Pratama 2018). It involves a company and another entity to which it is related, such as, for example, the chairman, a partner, a controlling shareholder, a director, a manager, etc. or also companies under their control, or with which they are affiliated, together with other companies controlled by the company itself and based on that it may have a direct or indirect effect on the company's value.

In Jordan, RPTs are governed by Articles of Corporate Governance Code for Shareholding Companies Listed on the Amman Stock Exchange which was issued by Jordan Securities Commission (JSC), which mentions that all related party transactions should be disclosed in the financial statements in a condensed note as an integral part of the audited financial statements and to be disclosed in details in the annual reports of the company's and ASE disclosures.

This study's model focused on all RPTs that were executed between the reporting company and parent company, subsidiaries and affiliated companies, associated companies, main Shareholders, directors and or managers. The impact of the independent variable (RPTs) over the dependent variable (company's value) was investigated in the presence of certain control variables which are (BIG) to see if the company's audited by one of the big audit firms, (SIZE) size of the company, (ROA) return on assets, (R\&D) research \& development intensity and (DIV) dividend yield. Some researchers such as (Wang and Yuan ,2015) in (China and Nekhili and Cherif ,2011) in France showed that RPT negatively affected firm value.

\section{Research Methodology}

The reason of this study is to analyze the correlation between transactions with related parties disclosed in the financial reports and the company's value. Accordingly, this manuscript makes in companies financial reports. Therefore, the related party transactions approached as follows: 
- Transactions with all Related Parties

- Transactions with, Parent company, Subsidiaries and Affiliated Companies

- Transactions with Associated Companies

- Transactions with Main Shareholders, Directors and /or Managers

This section discusses the population, sample selection and data collection method that used to evaluate study variables effect on the company's market value of Jordanian companies in all sectors, except the banks which represents $6 \%$ of the total entities listed in Amman Stock Exchange (15 banks of 241 listed entities).

\subsection{Research Population, Sample Selection and Data Collection Method}

This study includes all of the companies listed on Amman Stock Exchange (ASE) at year end of 2012 with total number of 226 companies. After excluding companies with missing data, the final sample size was 218 companies. For data collection, the annual reports and disclosure documents of each company will be indicated in the selected sample. In Jordan, it is mandatory as per guide issued by Amman Stock exchange Commission (ASEC) that any deal or contract exceeds the value of JD 50,000 made between the company and any of the following parties (RPTs') to be disclosed in the financial statements:

1. Company's affiliates and subsidiaries.

2. Board of directors members and company upper executive management.

3. Board directors members or the management committee, upper management and upper executive management of the affiliated company.

5. Any person owns more than $5 \%$ of the shares of the company or one of its affiliates.

6 . Relatives and partners of the above parties.

7. Saving funds of the company's employees.

8. The company's joint ventures with any other parties.

9. Companies under control of members of the board of directors and the upper executive management and their relatives.

\subsection{Variables and Operational Definition}


Table (I). Operational Definition of Variables and What They Measure

\begin{tabular}{ll}
\hline Variables' & \multicolumn{1}{c}{ Definition } \\
\hline $\begin{array}{l}\text { Dependent Variable } \\
\text { TQit }\end{array}$ & Tobin's Q \\
Independent Variables & \\
RPT & Transactions with all Related Parties \\
TPSAC & Transactions with, Parent company, Subsidiaries and Affiliated Companies \\
TAC & Transactions with Associated Companies \\
TMSDM & Transactions with Main Shareholders, Directors and /or Managers \\
Control Variables & \\
BIG & Audited by one of the big audit firms \\
SIZE & Size of the company \\
ROA & Return On Assets \\
R\&D & Research and Development intensity \\
DIV & Dividend yield \\
\hline
\end{tabular}

The variables will be measured as follows:

Tobin's Q (TQit) is measured by stock market capitalization plus book value of liabilities as a ratio of total assets.

RPT is measured by natural logarithm of the firm's total value of related party transactions.

TPSAC is measured by natural logarithm of the firm's total value of transactions with parent company, subsidiaries and affiliated companies.

TAC is measured by natural logarithm of the firm's total value of transactions with associated companies.

TMSDM is measured by natural logarithm of the firm's total value of transactions with main shareholders, directors and/or managers.

BIG is measured by 1 if the company is audited by a "Big Four", 0 otherwise.

SIZE is measured by total assets ( 1 big size; if TA $\geq 5$ million and 0 if $\mathrm{TA}<5$ million).

ROA is measured by dividing Earrings Before Interest, Tax, Depreciation and Amortization (EBITDA) on total assets.

R\&D is measured by dividing the volume of research and development expenses on the sales revenue.

DIV is measured by dividing the distributed dividend on the share price. 


\section{Macrothink}

\subsection{Conceptual Model}

\section{Control Variables}

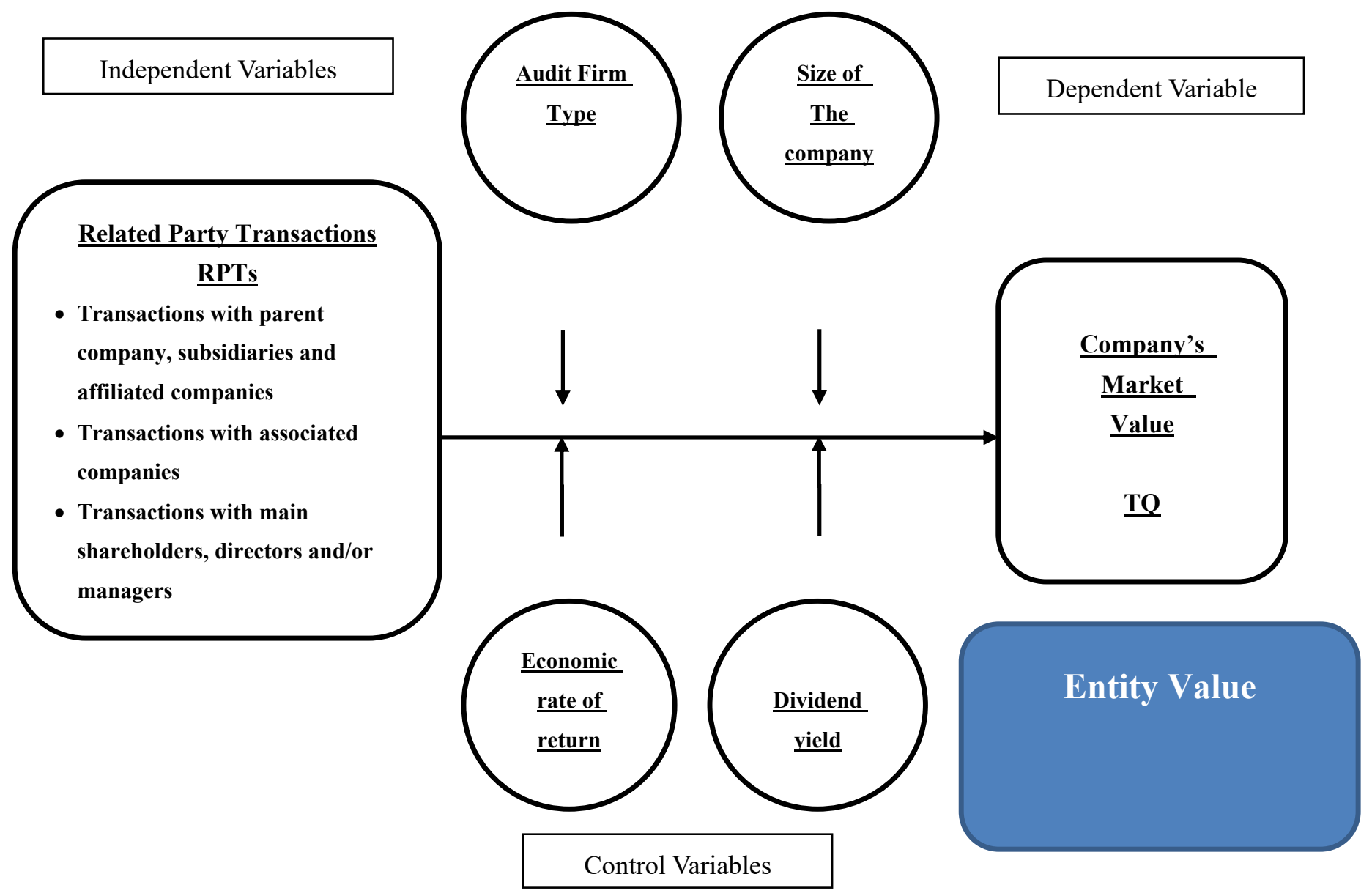

Figure (I). Conceptual Model

\subsection{Hypotheses}

The hypotheses are build based on the theoretical framework and the previous studies review that focused on the related-party transactions (RPTs) and its Impact on the company's value as the significance and the manipulative nature of related-party transactions (RPTs) and transparency in the disclosure important and relevant for investors who infer company value from disclosures. However, the disclosure of RPTs in proper way may not be cost effective because not all of the information that firms possess is value relevant to financial statement readers (Lo and Wong, 2016). Related party transactions could be used by companies to create strategic partnerships and efficiency gals. The RPTs also could be utilized by management and controlling shareholders to increase their wealth through expropriation (Fanania and Alya Firdausib, 2020). 
The hypotheses are modeled and will be tested using secondary data from latest annual reports and financial database for companies listed on Amman Stock Exchange (ASE).

Based on the previous studies the hypotheses will be stated and modeled as follows:

$\mathbf{H}_{01}$ : All related party transactions do not affect the company's market value in presence with control variables.

$\mathbf{H}_{\mathbf{0 2}}$ : Related party transactions with parent company, subsidiaries and affiliated companies do not affect the company's market value in presence with control variables.

H03: Related party transactions with associated companies do not affect the company's market value in presence with control variables.

H04: Related party transactions with main shareholders, directors and/or managers do not affect the company's market value in presence with control variables.

\subsection{Model, Measurement of Variables and Statistics}

This research is an empirical study which tests the correlation between (RPT's) and company's market value in Jordan. The researcher analyzed the data available in the annual reports and disclosure documents for the year ended 2012 of each company listed in Amman Stock. Simple and multiple regression tests are executed to examine the study's hypotheses; wither each category (TPSAC, TAC and TMSDM) has an impact on the company market value. The model will check, through the first, second and third equations laid down, the effect of each category of equations on the company's value, as measured by Tobin's Q in presence of control variables. Control variables were considered in the model include the type of the audit firm (BIG), company's size (SIZE) (1 if TA $\geq 5$ million \& 0 if TA $<5$ million), economic rate of return which is measured by the ROA (EBITDA divided by total assets), the R\&D intensity which is measured by dividing the volume of R\&D on turnover and the dividend yield which is measured by dividing distributed dividend on the share price. Therefore, the model can be expressed as follows:

Multiple regression analysis between each independent variable \& TQ in presence of control variables:

1- TQit $=\alpha 0+\alpha 1$ RPTit $+\alpha$ BBIGit $+\alpha$ 3SIZEit $+\alpha$ 4ROAit $+\alpha$ RR\&Dit $+\alpha$ 6DIVit + $\varepsilon 1$

2- TQit $=\alpha 0+\alpha$ 1TPSACit $+\alpha$ 2BIGit $+\alpha$ 3SIZEit $+\alpha$ 4ROAit $+\alpha$ RR\&Dit $+\alpha$ 6DIVit $+\varepsilon 1$

3- TQit $=\alpha 0+\alpha$ 1TACit $+\alpha$ 2BIGit $+\alpha$ 3SIZEit $+\alpha$ 4ROAit $+\alpha$ RR\&Dit $+\alpha$ 6DIVit + $\varepsilon 1$

4- $\quad$ TQit $=\alpha 0+\alpha$ 1TMSDMit $+\alpha$ 2BIGit $+\alpha 3$ SIZEit $+\alpha$ 4ROAit $+\alpha$ 5R\&Dit $+\alpha$ 6 DIVit $+\varepsilon 1$

The collected data were coded and analyzed. Descriptive analysis, variance inflation factor (VIF), matrix of correlation coefficients between study variables have been implemented then 
the hypotheses were tested.

\section{Data Analysis and Results}

This section shows the results that come out after analyzing the data collected for the study sample. The first part will discuss the descriptive analysis for the study variables, second part is variance inflation factor (VIF), third part is matrix of correlation coefficients between study variables (main variables and the control variables), multiple regressions analysis will be discussed in the fourth part as well, hypotheses testing results in the fifth part.

\subsection{Descriptive Analysis}

Table (II) indicates that most of companies listed on Amman stock exchange were widely executing transactions with related parties in their normal course of business as the average for related party transactions RPTs were made in 218 listed companies in ASE was 5.68 and standard deviation reached 1.67. Transactions with the main shareholders, directors and/or managers are also executed widely in the shareholding companies, the average for total transactions with main shareholders, directors and/or managers TMSDM were made in 218 listed companies in ASE was 4.93 and the standard deviation was 1.80 as all of shareholding companies have key management runs their business, the cost of this management personnel considered the most common related party transactions could be seen in the disclosure of RPT. The average for total transactions with parent, subsidiaries and affiliated companies TPSAC were made in 218 listed companies in ASE was 1.88 and the standard deviation was 2.84, and this kind of transactions had the least observation on average as they may be eliminated in the group level or in the parent company's financial statements. Transactions with associated companies were considered by KPMG paper which was mentioned earlier in literature review section as the most complicated category of transaction, thus most of companies are trying to minimize those transactions. The average for total transactions with associated companies TAC were made in 218 listed companies in ASE was 2.14 and standard deviation was 2.90 .

Table (II). Descriptive Statistics of Study Variables

\begin{tabular}{cccccc}
\hline Variables & $\mathbf{N}$ & Minimum & Maximum & Mean & Std. Deviation \\
\hline RPT & 218 & 0.00 & 9.12 & 5.68 & 1.67 \\
TPSAC & 218 & 0.00 & 9.12 & 1.88 & 2.84 \\
TAC & 218 & 0.00 & 8.43 & 2.14 & 2.90 \\
TMSDM & 218 & 0.00 & 8.36 & 4.93 & 1.80 \\
SIZE & 218 & 0.00 & 1.00 & 0.82 & 0.39 \\
BIG & 218 & 0.00 & 1.00 & 0.40 & 0.49 \\
ROA & 218 & 0.00 & 84.07 & 6.54 & 9.22 \\
DIV & 218 & 0.00 & 2.40 & 0.06 & 0.20 \\
\hline
\end{tabular}




\section{Macrothink}

Related to control variables, the observation was on average $82 \%$ of the companies have share capital more than JOD 5 million, based on research theory and assumptions those companies were considered as big size companies from the sample of 218 companies listed in ASE. On average $40 \%$ of the companies were audited by big four audit firms which are KPMG, Deloitte Touche Tohmatsu, Price water house Coopers and Ernst \& Young and the remaining of 60 percent were audited by non-big four audit firms and standard deviation was 0.49 . The average of ROA was $6.54 \%$ and standard deviation was 9.22 were observed means that companies are earning on around $7 \%$ on their assets and this result cannot be justified as efficient or inefficient as the analysis was for different industries. The distributed dividends on average was 0.06 which means that this the percentage of dividends yield that most of 218 listed companies in ASE was considered when they distribute the dividends.

\subsection{Variance Inflation Factor (VIF)}

Before implementing regression analysis to test the hypothesis and to assess the multi-collinearity between independent variables; the variance inflation factor (VIF) and tolerance are used to quantify the intensity of multi-collinearity between the study independent variables using the following formula: Variance Inflation Factor VIF $=1 \div(1$ $\mathrm{R}^{2}$ ). The VIF provides us with the index mentioned in below table that measures how much the variance of discrete variables.

Table (III). Results of (VIF) of Independent Variables

\begin{tabular}{ccc}
\hline Variable & Tolerance & VIF \\
\hline RPT & 0.771 & 1.297 \\
TPSAC & 0.950 & 1.053 \\
TAC & 0.955 & 1.047 \\
TMSDM & 0.848 & 1.179 \\
\hline
\end{tabular}

With reference to table (III) appears that the value of VIF is less than 10 for all the independent variables and ranged between 1.047 and 1.297, also the variation value for all variables was more than (0.05) and ranged between 0.771 and 0.955 , accordingly we can say that there is no problem indicates the existence of multi-collinearity between independent variables, this leads us to accept the variation in the level of each variable of the study independent variables (Kutner et al. 2004).

\subsection{Matrix of Correlation Coefficients between Study Variables}

Table (IV) the analysis of the correlation matrix shows that the significant correlation coefficients between study variables ranged between -0.210 and 0.706 . 
Table (IV). Matrix of Correlation Coefficient between Study Variables (RPT, TPSAC, TAC, TMSDM, TQ, SIZE, BIG, ROA, and DIV)

\begin{tabular}{cccccccccc}
\hline Variables & RPT & TPSAC & TAC & TMSDM & TQ & SIZE & BIG & ROA & DIV \\
\hline RPT & - & $0.334^{* *}$ & $0.352^{* *}$ & $0.706^{* *}$ & -0.015 & $0.449^{* *}$ & $0.197^{* *}$ & -0.044 & 0.122 \\
TPSAC & - & 0.094 & 0.008 & 0.030 & $0.145^{*}$ & 0.006 & -0.047 & $0.143^{*}$ \\
TAC & & & - & 0.053 & $-0.161^{*}$ & $0.185^{* *}$ & 0.026 & -0.055 & 0.078 \\
TMSDM & & & & - & 0.00 & $0.323^{* *}$ & $0.250^{* *}$ & -0.026 & 0.127 \\
TQ & & & & & - & $-0.210^{* *}$ & 0.049 & $0.220^{* *}$ & $0.460^{* *}$ \\
SIZE & & & & & & - & $0.217^{* *}$ & $0.135^{* *}$ & 0.048 \\
BIG & & & & & & & - & 0.084 & $0.149^{*}$ \\
ROA & & & & & & & - & $0.187^{* *}$ \\
DIV & & & & & & & & & - \\
\hline
\end{tabular}

$* *$ Correlation is significant at the 0.01 level
$* \quad$ Correlation is significant at the 0.05 level

A first reading of table (IV) shows that over all RPTs have significant positive effect with all independent variables TPSAC, TAC and TMSDM, the effects were $0.334,0.352$ and 0.706 respectively at $(\alpha \leq 0.01)$ level, while the negative effect on the dependent variable the company's value which measured by Tobin's Q was insignificant. On the other hand, correlation coefficient was statistically positive significant at $(\alpha \leq 0.01)$ level with two of control variables that are company's size and the audit firm type. The market value is not affected by executing these transactions and this result is contrary to what obtained by Weiju and Cherif (2011).

Results of correlation matrix showed that transactions with parent company, subsidiaries \& affiliated companies have positive significant at $(\alpha \leq 0.05)$ level with two control variables that are company's size and dividends yield. Otherwise, the transactions with associated companies have negative impact at the company's value that was statistically significant at $(\alpha \leq 0.05)$ level and the effect was -0.161 , in other words; these transactions have greater effect in depreciating the company's value. But the effect of (TAC) on the company's size where positive as the effect was 0.185 at $(\alpha \leq 0.01)$ level. The table shows that there is a significant correlation between those companies makes transactions with main shareholders, directors and/or managers was statistically positive significant at $(\alpha \leq 0.01)$ level with two control variables that are company's size and the audit firm type. Finally, the correlation was significantly negative between dependent variable TQ \& the company's size at $(\alpha \leq 0.01)$ level and the effect was -0.210 while the correlation where significantly positive with both two control variables that are ROA and dividends yield that was statistically significant at $(\alpha \leq 0.01)$ level; means that the companies which distributed dividends have more market value than those who had not, this is support that the dividend yield was included in our research model as measured by the ratio of the dividend per share to the share price as control variable assuming that the distribution of dividends continuously is an indication of the protection for outside or minority shareholders rights, but there was no significant impact of dividend yield 
on the frequency of all categories of related party transactions, except for TPSAC and results in this area was consistent with Weiju and Cherif (2011).

From the table it can be seen that the correlation between the company's size and audit firm type was positively significant at $(\alpha \leq 0.01)$ level was 0.217 , that means that most of the big size companies are audited by big four audit firms, the same can be noted with ROA as the effect was 0.135 that positively significant at $(\alpha \leq 0.01)$ level. Finally, audit firm type and ROA intensity variables have positive correlation with dividends yield variable, the effects ware 0.149 at $(\alpha \leq 0.05)$ level and 0.187 at $(\alpha \leq 0.01)$ level respectively.

\section{4 Least Squares Regression Analysis}

\section{Related party transactions disclosed and the company's market value.}

To detect the correlation between independent variables and dependent variable company's value which is measured by Tobin's Q (TQ), the simple and multiple regression analysis are applied by using the least squares regression to test the impact of the independent variables on the dependent variable where is the simple regression was without the control variables but the multiple in the presence of control variables (BIG, SIZE, ROA \& DIV). The control variable ( $R \& D$ intensity) was eliminated due to non-availability of enough data from the sample. The result of the simple regression analysis showed that the impacts of all kinds of related party transactions were insignificant, except for the impact of transactions with associated companies TAC on the company's market value without the control variables that was negatively significant $(-0.161)$ at $(\alpha \leq 0.05)$ level .

\subsection{Hypotheses Testing}

\section{The first hypothesis: All Related party transactions do not affect the company's market} value in presence of control variables.

To test this hypothesis, and to detect the correlation between independent variable transactions with all related parties (RPTs) and dependent variable Tobin's Q (TQ), the multiple regression analysis was applied to test the impact of the independent variable RPTs on the dependent variable TQ in presence of the control variables (BIG, SIZE, ROA \& DIV) using the following equation:

TQit $=\alpha_{\alpha 0}+{ }_{\alpha 1} \mathrm{RPT}_{\text {it }}+{ }_{\alpha 2} \mathrm{BIGit}+{ }_{\alpha} \mathrm{SIZE}_{\mathrm{it}}+{ }_{\alpha}{ }_{4} \mathrm{ROA}_{\mathrm{it}}+{ }_{\alpha} \mathrm{DIV}_{\mathrm{it}}+\varepsilon_{1}$

Table (V) represents the results of multiple regressions between independent variable (RPT) and dependent variable (TQ) in the presence of the control variables. 
Table (V). Results of Multiple Regression Analysis between RPT \& TQ in presence of Control Variables

\begin{tabular}{cccccc}
\hline \multicolumn{2}{c}{ Independent variable } & Beta & "t" value & "f" value & Result \\
\hline \multirow{4}{*}{ with } & RPT & 0.018 & 0.271 & & \\
control & SIZE & $-0.185^{*}$ & $-2.717^{*}$ & & \\
variables & BIG & 0.013 & 0.208 & $14.935^{* *}$ & Hypothesis \\
& ROA & 0.115 & 1.887 & & \\
& DIV & $0.426^{*}$ & $6.932^{*}$ & & \\
\hline
\end{tabular}

Dependent variable: TQ

(R) Value reached $(0.510)$

$\left(\mathrm{R}^{2}\right)$ Value reached $(0.260)$

(Adjusted $\mathrm{R}^{2}$ ) Value reached $(0.243)$

The results of multiple regressions analysis in table (V) shows that there is an explanation power of the model which is justified by " $f$ " value (14.935) was significant at $(\alpha \leq 0.05)$, and adjusted Coefficient of Determination (Adjusted $\mathrm{R}^{2}=0.243$ ) which means that the change in all related party transactions (RPT) (Independent Variable) will interpret 24.3\% of the change in TQ. The result shows that the impact of all related party transactions on the company's market value in presence of control variable was insignificant. This result is contrary with what was found by (Weiju and Moez, 2011) and this might be due to different model carried out in their research such as sample size of 85 companies listed in Paris Stock Exchange during 2002-2005. Moreover the table shows that the effect the company's size was significantly negative $(-0.185)$ at $(\alpha \leq 0.05)$ on the company's value while the effect of dividends yield was significantly positive $(0.426)$ at $(\alpha \leq 0.05)$; this means that in companies executing RPTs the higher the company's size the higher the company's value and the company's value is positively increased in the companies distributed dividends to their shareholders, therefor, distribution of dividends could be considered an indication of the protection for outside or minority shareholders rights. Abdullatif et al. (2019) finds in there study that there is no statistically significant relation was found between RPTs and firm profitability or board political connections which was consist with the hypothesis. Also the result was consist with Fanania and Alya Firdausib (2020) study which finds that he disclosure value of related party transactions in the financial position and the value of related party transactions have no value relevance. Therefore we accept the first null hypnosis that the all related party transactions do not affect the company's market value in presence of control variables.

The second hypothesis: Related party transactions with parent company, subsidiaries and affiliated companies do not affect the company's market value in presence of control variables.

To test this hypothesis, and to detect the correlation between independent variable transactions with parent company, subsidiaries and affiliated companies (TPSAC) and dependent variable Tobin's Q (TQ), the multiple regression analysis was applied to test the impact of the independent variable TPSAC on the dependent variable TQ in presence of the 
control variables (BIG, SIZE, ROA \& DIV) using the following equation:

TQit $=\alpha_{0}+{ }_{\alpha 1}$ TPSAC $_{\text {it }}+{ }_{\alpha 2} \mathrm{BIG}_{\mathrm{it}}+{ }_{\alpha 3} \mathrm{SIZE}_{\mathrm{it}}+{ }_{\alpha} \mathrm{ROA}_{\mathrm{it}}+{ }_{\alpha_{5}} \mathrm{DIV}_{\mathrm{it}}+\varepsilon_{1}$

Table (VI) represents the results of multiple regressions between independent variable (TPSAC) and dependent variable (TQ) in the presence of the control variables.

Table (VI). Results of Multiple Regression Analysis between TPSAC \& TQ in Presence of Control Variables

\begin{tabular}{cccccc}
\hline \multicolumn{2}{c}{ Independent variable } & Beta & " $\mathbf{t}$ " value & "f" value & Result \\
\hline \multirow{4}{*}{ with } & TPSAC & 0.000 & 0.006 & & \\
control & SIZE & $-0.177^{*}$ & $-2.844^{*}$ & $14.916^{*}$ & \\
variables & BIG & 0.014 & 0.233 & & Accept Null \\
& ROA & 0.115 & 1.879 & & Hypothesis \\
& DIV & $0.428^{*}$ & $6.948^{*}$ & & \\
\hline
\end{tabular}

Dependent variable: TQ $\quad$ (R) Value reached $(0.510)$

$\left(\mathrm{R}^{2}\right)$ value reached $(0.260)$

(Adjusted $\mathrm{R}^{2}$ ) value reached $(0.243)$

The results of multiple regressions analysis in table (VI) shows that there is an explanation power of the model which is justified by " $f$ " value (14.916) was significant at $(\alpha \leq 0.05)$, and adjusted Coefficient of Determination (Adjusted $\mathrm{R}^{2}=0.243$ ) which means that the change in variable transactions with parent company, subsidiaries and affiliated companies (TPSAC) (Independent Variable) will interpret $24.3 \%$ of the change in TQ. The result shows that the impact of transactions with parent company, subsidiaries and affiliated companies on the company's market value in presence of control variable was insignificant. This result is contrary with what was found by (Weiju and Cherif, 2011) this might be due to different model carried out in their research such as sample size of 85 companies listed in Paris Stock Exchange during 2002-2005. Moreover the table shows that the effect the company's size was significantly negative $(-0.177)$ at $(\alpha \leq 0.05)$ on the company's value while the effect of dividends yield was significantly positive $(0.428)$ at $(\alpha \leq 0.05)$; this means that in companies executing TPSAC the higher the company's size the higher the company's value and the company's value is positively increased in the companies distributed dividends to their shareholders, therefor, distribution of dividends could be considered an indication of the protection for outside or minority shareholders rights. Abdullatif et al. (2019) finds in there study that there is no statistically significant relation was found between RPTs and firm profitability or board political connections which was consist with the hypothesis. Also, the result is consist with Fanania and Alya Firdausib (2020) study which finds that he disclosure value of related party transactions in the financial position and the value of related party transactions have no value relevance. Therefore, we accept the second null hypnosis that the TPSAC do not affect the company's market value in presence of control variables. 


\section{Al Macrothink}

Journal of Corporate Governance Research

ISSN 1948-4658

2021, Vol. 5, No. 1

The third hypothesis: Related party transactions with associated companies do not affect the company's market value in presence of control variables.

To test this hypothesis, and to detect the correlation between independent variable transactions with associated companies (TAC) and dependent variable Tobin's Q (TQ), the multiple regression analysis was applied to test the impact of the independent variable TAC on the dependent variable TQ in presence of the control variables (BIG, SIZE, ROA \& DIV) using the following equation:

TQit $=\alpha 0+\alpha$ 1TACit $+\alpha$ 2BIGit $+\alpha$ 3SIZEit $+\alpha$ 4ROAit $+\alpha$ 5DIVit $+\varepsilon 1$

Table (VII) represents the results of multiple regressions between independent variable (TAC) and dependent variable (TQ) in the presence of the control variables.

Table VII. Results of Multiple Regression Analysis between TAC \& TQ in Presence of Control Variables

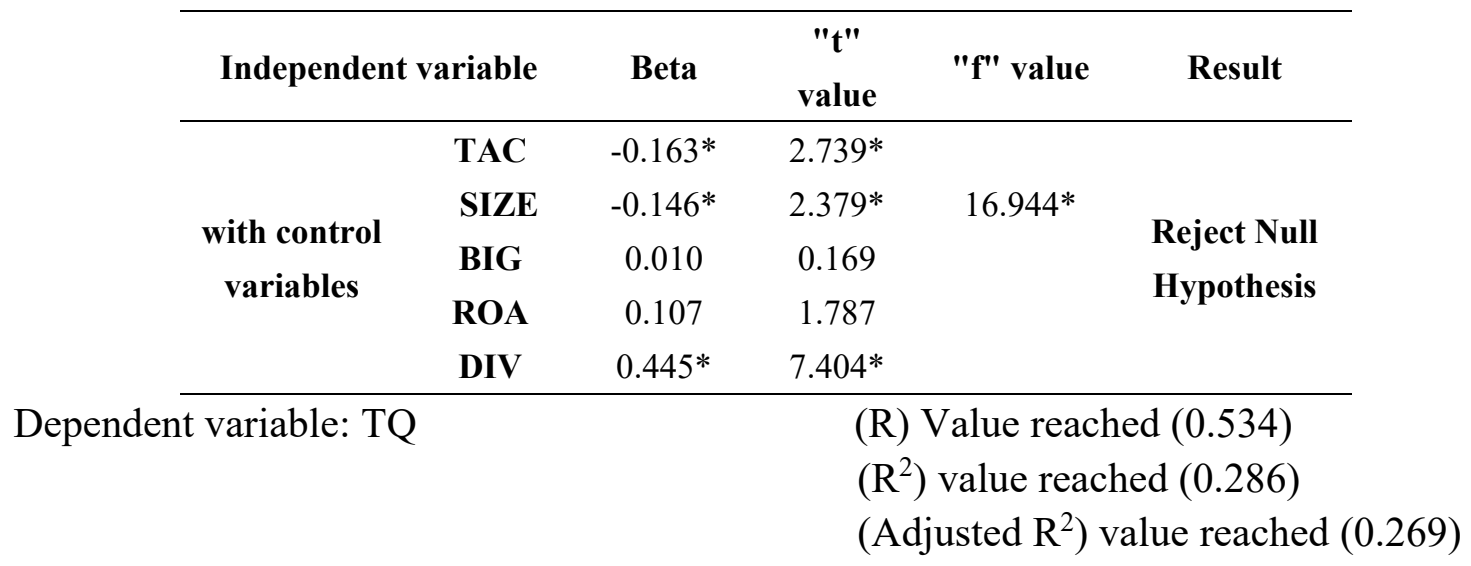

The results of multiple regressions analysis in table (VII) shows that there is an explanation power of the model which is justified by "f" value (16.944) was significant at $(\alpha \leq 0.05)$ level, and adjusted Coefficient of Determination (Adjusted $\mathrm{R}^{2}=0.269$ ) which means that the change in variable transactions with associated companies (TAC) (Independent Variable) will interpret $26.9 \%$ of the change in TQ. The result shows that the impact of transactions with associated companies on the company's market value in presence of control variable was negatively significant $(-0.163)$ at $(\alpha \leq 0.05)$ level This result is consistent with what was found by (Weiju and Cherif, 2011) and one of the two theories raised by (Michele Pizzo, 2013) that transactions with related parties considered " conflict of interests; opportunistic management that harms the company's value and considers only the interest of directors. Moreover the table shows that the effect the company's size was significantly negative $(-0.146)$ at $(\alpha \leq 0.05)$ on the company's value while the effect of dividends yield was significantly positive $(0.445)$ at $(\alpha \leq 0.05)$; this means that in companies executing TAC the higher the company's size the higher the company's value and the company's value is positively increased in the companies distributed dividends to their shareholders, therefor, distribution of dividends could be considered an indication of the protection for outside or minority shareholders rights. The 
result is contrary with the results of Abdullatif et al., (2019) finds in there study that there is no statistically significant relation was found between RPTs and firm profitability or board political connections. Also the result is contrary with Fanania and Alya Firdausib (2020) study which finds that he disclosure value of related party transactions in the financial position and the value of related party transactions have no value relevance. Therefore we reject the third null hypnosis that the TAC do not affect the company's market value in presence of control variables.

The fourth hypothesis: Related party transactions with main shareholders, directors and/or managers do not affect company's market value in presence of control variables.

To test this hypothesis, and to detect the correlation between independent variable transactions with main shareholders, directors and/or managers (TMSDM) and dependent variable Tobin's Q (TQ), the multiple regression analysis was applied by using the least squares method to test the impact of the independent variable TMSDM on the dependent variable TQ in the presence of the control variables (BIG, SIZE, ROA \& DIV). The following equation show that:

To test this hypothesis, and to detect the correlation between independent variable transactions with main shareholders, directors and/or managers (TMSDM) and dependent variable Tobin's Q (TQ), the multiple regression analysis was applied to test the impact of the independent variable TMSDM on the dependent variable TQ in presence of the control variables (BIG, SIZE, ROA \& DIV) using the following equation:

TQit $=\alpha 0+\alpha 1$ TMSDMit $+\alpha 2$ BIGit $+\alpha 3$ SIZEit $+\alpha$ 4ROAit $+\alpha$ DDIVit $+\varepsilon 1$

Table (VIII) represents the results of multiple regressions between independent variable (TMSDM) and dependent variable (TQ) in the presence of the control variables.

Table VIII. Results of Multiple Regression Analysis between TMSDM \& TQ in Presence of Control Variables

\begin{tabular}{lccccc}
\hline \multicolumn{2}{c}{ Independent variable } & Beta & $\begin{array}{c}\text { "t" } \\
\text { value }\end{array}$ & "f" value & Result \\
\hline \multirow{4}{*}{ with control } & TMSDM & 0.003 & 0.043 & & \\
variables & BIGE & $-0.178^{*}$ & $-2.770^{*}$ & $14.916^{*}$ & Accept Null \\
& ROA & 0.014 & 0.223 & & Hypothesis \\
& DIV & 0.115 & 1.882 & & \\
\hline
\end{tabular}

Dependent variable: TQ

(R) Value reached $(0.510)$

$\left(R^{2}\right)$ value reached $(0.260)$

(Adjusted $\mathrm{R}^{2}$ ) value reached $(0.243)$ 


\section{MlMacrothink}

Journal of Corporate Governance Research ISSN 1948-4658 2021, Vol. 5, No. 1

The results of multiple regressions analysis in table (VIII) shows that there is an explanation power of the model which is justified by " $f$ " value (14.916) was significant at $(\alpha \leq 0.05)$, and adjusted Coefficient of Determination (Adjusted $\mathrm{R}^{2}=0.243$ ) which means that the change in variable transactions with main shareholders, directors and/or managers (TMSDM) (Independent Variable) will interpret $24.3 \%$ of the change in TQ. The result shows that the impact of transactions with main shareholders, directors and/or managers on the company's market value in presence of control variable was insignificant. This result is contrary with what was found by (Weiju and Cherif, 2011) this might be due to different model carried out in their research such as sample size of 85 companies listed in Paris Stock Exchange during 2002-2005. Moreover the table shows that the effect the company's size was significantly negative $(-0.178)$ at $(\alpha \leq 0.05)$ on the company's value while the effect of dividends yield was significantly positive $(0.428)$ at $(\alpha \leq 0.05)$; this means that in companies executing TMSDM the higher the company's size the higher the company's value and the company's value is positively increased in the companies distributed dividends to their shareholders, therefor, distribution of dividends could be considered an indication of the protection for outside or minority shareholders rights. The result is contrary with the results of Abdullatif et al., (2019) finds in there study that there is no statistically significant relation was found between RPTs and firm profitability or board political connections. Also the result is contrary with Fanania and Alya Firdausib (2020) study which finds that he disclosure value of related party transactions in the financial position and the value of related party transactions have no value relevance. Therefore we reject the fourth null hypnosis that the TMSDM do not affect the company's market value in presence of control variables.

\section{Research Conclusions and Recommendations}

\subsection{Research Conclusions}

This study provides logical explanation for the correlation between related party transactions disclosed and company value (Tobin's Q) which was examined by operationalizing the related party transactions into three forms that are: Transactions with parent company, subsidiaries and affiliated companies (TPSAC), Transactions with associated companies (TAC) and Transactions with main shareholders, directors and/or managers (TMSDM). The results show "statistically" that the impact of certain related party transactions on company's value was negative which represented by transactions with associated companies which is significantly influenced by two control variables; size of the company (SIZE), and dividend yield (DIV) in this area our results were consistent with what found by (Weiju and Cherif, 2011). The main purpose for this study was to illustrate the correlation between related party transactions disclosed and company value (Tobin's Q) in Jordan. The statistical results are shedding the light on the phenomenon that most of listed companies in Jordan are considered the RPTs widely. Most of the hired directors, key managements and shareholders are running the companies either themselves, their family members or relatives. Understanding the influence of this phenomenon and the research findings will lead to the possibility of controlling or may be eliminating the conflicts of interest that might arise between 
shareholders (principals) and managers which affect the potential costs and benefits of the transaction between shareholders (principals) and all related parties that the results could fulfill economic gain and not harm the company. Also, the findings support that it could be noted in companies executing transactions with related parties; the higher the company's size the lower the company's market value. Finally, it was founded that distribution of dividends could be considered as an indication of the protection for outside shareholders' rights and minority shareholders' interests.

The practical implications of the research findings could be important for Amman stock Exchange Commission in Kingdom of Jordan that they must have more focus of the enhancement the regulations related to the RPTs and the transparency in announcing such transactions thorough the full disclosure of RPTs to protect the rights for the non-controlling interests through monitoring the related party transactions RPTs to minimize or eliminate any manipulation for the company's results or values. The result was consistent with the findings of include that regulatory authorities in Jordan should enhance regulations to protect small shareholders and to restrict the power of controlling / major shareholders that makes them able to engage in illegitimate RPTs.

\subsection{Research Recommendations}

This study findings and implications could be utilized in future research studies in Jordan on RPTs; which should be focused on the classification and interpretation of purposes for using RPTs and the nature of those transactions within the bundle of guidelines issued by Amman Stock Exchange Commission. Thus, the company can be rely on the efficient transactions with related party that are aligned with guidelines of stock exchange commission and SOX. Also, future studies could focus on analyzing the RPTs executed in banks in addition to those executed in all companies listed in ASE as the banking sector have different nature of industry which required more detailed disclosures and details as they are subject to central bank regulations in addition to SEC.

In separate note, the results of this study could be of interest to all individuals. The First thing, the related regulations for the auditing of related party transactions, results are likely to be of important to decision makers related to policies as they are consistent with corporate governance being an important factor in financial market effectiveness. Second thing is, our results are likely to be of interest to creditors and both controlling and non-controlling shareholders / investors as they evaluating the transparency of information included in related party transactions. The Third thing, these results contribute to the related party transactions future research as they're providing evidence on the impact of related party transactions on company's values is having a correlation in presence of the corporate governance and other control variables such as dividends, ROA, R\&D...etc., also contributes to the corporate governance research by focusing the importance of corporate governance in enhancing company performance and mitigating risk of manipulating the interests of RPTs. Last, the results are potentially useful to decision makers and directors because they proposed that the performance of the related party transactions should be disclosed in proper way and as per the market regulations. 


\section{References}

Abdullatif M., Alhadab M., \& Mansour I. (2019). Determinants of Related Party Transactions in Jordan: Financial and Governance Factors. Australasian Accounting, Business and Finance Journal, 13(1), 44-75. https://doi.org/10.14453/aabfj.v13i1.6

AlKurdi A., Al Nimer M., \& Dabaghia M. (2017). Accounting Conservatism and Ownership Structure Effect: Evidence from Industrial and Financial Jordanians Listed Companies. International Journal of Economics and Financial Issues, 217, 608-619. https://doi.org/10.5890/JEAM.2017.06.007

Chena J., Cheng P., \& Xiao X. (2011). Related party transactions as a source of earnings management. Applied Financial Economics, 21, 165-181. https://doi.org/10.1080/09603107.2010.528361

Cheung Y., Rau P., \& Stouraitis A. (2009). Helping Hand or Grabbing Hand? Central vs. Local Government Shareholders in Chinese Listed Firms. Review of Finance, 14(4), 669-694. https://doi.org/10.1093/rof/rfp024

Cheung, Y., Rau P., \& Stouraitis, A. (2006). Tunneling, propping and expropriation evidence from connected party transactions in Hong Kong. Journal of Financial Economics, 82, 343-86. https://doi.org/10.1016/j.jfineco.2004.08.012

Diab, A.A., Aboud, A., \& Hamdy, A. (2019). The impact of related party transactions on firm value: Evidence from a developing country. Journal of Financial Reporting and Accounting, 17(3), 571-588. https://doi.org/10.1108/JFRA-08-2018-0064

Fanania Z., \& Firdausib A. (2020). Value Relevance for Disclosure of Transactions Value and Level of Disclosure of Related Party Transactions. International Journal of Innovation, Creativity and Change, 13(10).

Friedman, E., Johnson, S., \& Mitton, T. (2003). Propping and tunneling. Journal of Comparative Economics, 31, 732-50. https://doi.org/10.1016/j.jce.2003.08.004

Johnson, S., \& Shleifer, A. (2004). Privatization and Corporate Governance, NBER-EAST Asia Seminar on Economics. University of Chicago Press, Chicago, ISBN: 0-226-38679-1.

Kohlbeck M., \& Mayhew B. (2010). Valuation of firms that disclose related party

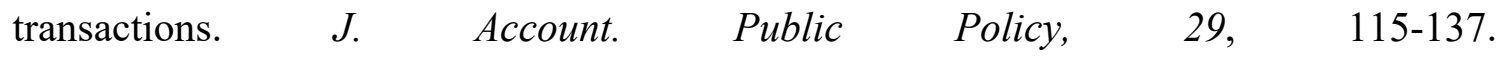
https://doi.org/10.1016/j.jaccpubpol.2009.10.006

KPMG (2009). First Impression of amendments to IAS 24 - related party disclosure. Amman, Jordan.

Kutner, M. H., Nachtsheim, C. J., \& Neter, J. (2004). Applied Linear Regression Models (4th ed.). Burr Ridge, IL: McGraw-Hill Irwin.

Lo, Agnes W. Y., \& Wong, Raymond M. K. (2016). Silence is golden? Evidence from disclosing related-party transactions in China. Journal of Accounting and Public Policy, 
35(5), 540-564. https://doi.org/10.1016/j.jaccpubpol.2016.06.002

Maggie P. Williams \& Dennis W. Taylor (2013). Corporate propping through related-party transactions - The effect of China's securities regulations. International Journal of Law and Management, 55(1), 28-41. https://doi.org/10.1108/17542431311303804

Michele P. (2013). Related party transactions under a contingency perspective. Journal of Management \& Governance, 17(2), 330-137.

Piesse J., Strange R., \& Toonsi F. (2012). Is there a distinctive MENA model of corporate governance? Journal of Management \& Governance, 16, 645-681. https://doi.org/10.1007/s10997-011-9182-5

Pratama A. (2018), Do Related Party Transactions and Tax Avoidance Affect Firm Value? Review of Integrative Business and Economics Research, 7, 106-116.

Ramachandran J., Alam N., \& Goh C. (2020), A win-win situation for both managers and shareholders: A study of ASEAN corporate governance. Managerial Finance, 46(8), 977-1000. https://doi.org/10.1108/MF-07-2018-0308

Rayngaert M., \& Thomas M. (2012), Not All Related Party Transactions(RPTs) Are the same : Ex Ante Versus Ex Post RPTs. Journal of International Accounting Research, 50(3), 845-882. https://doi.org/10.1108/MF-07-2018-0308

Riyantoa, Y. E., \& Toolsema, L. A. (2008) Tunneling and propping: a justification for pyramidal ownership. Journal of Banking and Finance, 32, 2178-87. https://doi.org/10.1016/j.jbankfin.2007.12.044

Sanchez C., Senra C., \& Alemán J. (2017), Related-Party Transactions, Dominant Owners and Firm Value. BRQ Business Research Quarterly, 20(1), 4-17. https://doi.org/10.1016/j.brq.2016.07.002

Thomas, W., Herrmann, D., \& Inoue, T. (2004). Earnings management through affiliated transactions. Journal of International Accounting Research, 3, 1-25. https://doi.org/10.2308/jiar.2004.3.2.1

Wang J., \& Yuan H. (2012). The Impact of Related Party Sales by Listed Chinese Firms on Earnings Informativeness and Earnings Forecasts. Forthcoming International Journal of Business, 17(3), 259-275.

Weiju M., \& Cherif M. (2011). Related parties' transactions and firm's market value: the French case. Review of Accounting and Finance, 10(3), 291-315. https://doi.org/10.1108/14757701111155806

William, P., Erica, D., Alan, J., Wade, H., Keith, B., Maria B., Samantha, C., Peter, F., Bob, C., Timothy, F.S., Leigh, G., \& Rodger, T. (2015). Opportunistic management of estuaries under climate change: A new adaptive decision-making framework and its practical application. Journal of Environmental Management, 163, 214-223. https://doi.org/10.1016/j.jenvman.2015.08.021 
Yeh Y., Shu P., \& Su Y. (2012). Related-party transactions and corporate governance: The evidence from the Taiwan stock market. Pacific-Basin Finance Journal, 20, 755-776. https://doi.org/10.1016/j.pacfin.2012.02.003

Zhu Y., \& Zhu X. (2012). Impact of the Share Structure Reform on the Role of Operating Related Party Transactions in China. Emerging Markets Finance \& Trade, 48(6), 73-94. https://doi.org/10.2753/REE1540-496X480604

\section{Copyright Disclaimer}

Copyright for this article is retained by the author(s), with first publication rights granted to the journal.

This is an open-access article distributed under the terms and conditions of the Creative Commons Attribution license (http://creativecommons.org/licenses/by/3.0/). 